\title{
The roots of accomplishment
}

\section{From a New Jersey beauty parlour to cutting-edge genetics by way of her own alopecia, Angela Christiano's life has all been tied up with hair. Helen Pearson meets a woman whose head is full of the stuff that covers it.}

$\mathrm{N}$ o one forgets their first encounter with Angela Christiano. For Jorge Frank, it was in an office at New York's Columbia University in 1995. "In walks this blizzard of a woman with the bright smile and the big hair and these long fingernails," recalls Frank, a molecular dermatologist at University Hospital Maastricht in the Netherlands. "I thought: 'This is a rock star not a scientist'."

Christiano certainly cuts an arresting figure. Deep-brown and bronze tresses erupt from her head in a gravity-defying explosion and surge over her shoulders. Her perfect make-up and carefully manicured nails complete an image that is the antithesis of a stereotypical scientist.

But for Christiano, hair is not just an adornment. It is a filament that binds together her appearance, her family, her personal life and her work. Descended from two generations of hairdressers, she came to appreciate hair's true importance when her own locks began to fall out in an episode of alopecia areata. Working at Columbia, she immediately shifted the focus of her research from skin disease to hunting down the genes that underlie human hair disorders, such as an atavistic condition in which people sprout thick hair all over their faces. Her scientific work may even end up with a cosmetic use, saving men and women with normal but nevertheless unwanted hair from shaving, waxing and depilation.

\section{Grooming talent}

Christiano grew up in New Jersey with an unusual appreciation for the importance of personal grooming. Hair and nails - "ectodermal appendages", as she now calls them - were her family's bread and butter. Her grandparents had set up a barber's shop after immigrating from Italy; her mother worked as a hairdresser and beautician. Christiano spent after-school hours sweeping up hair in her mother's shop. "I didn't realize it at the time," she says, "but I was becoming a keen observer."

Many of her schoolmates went on to become hairdressers and beauticians, and Christiano's family expected her to stay at home until she

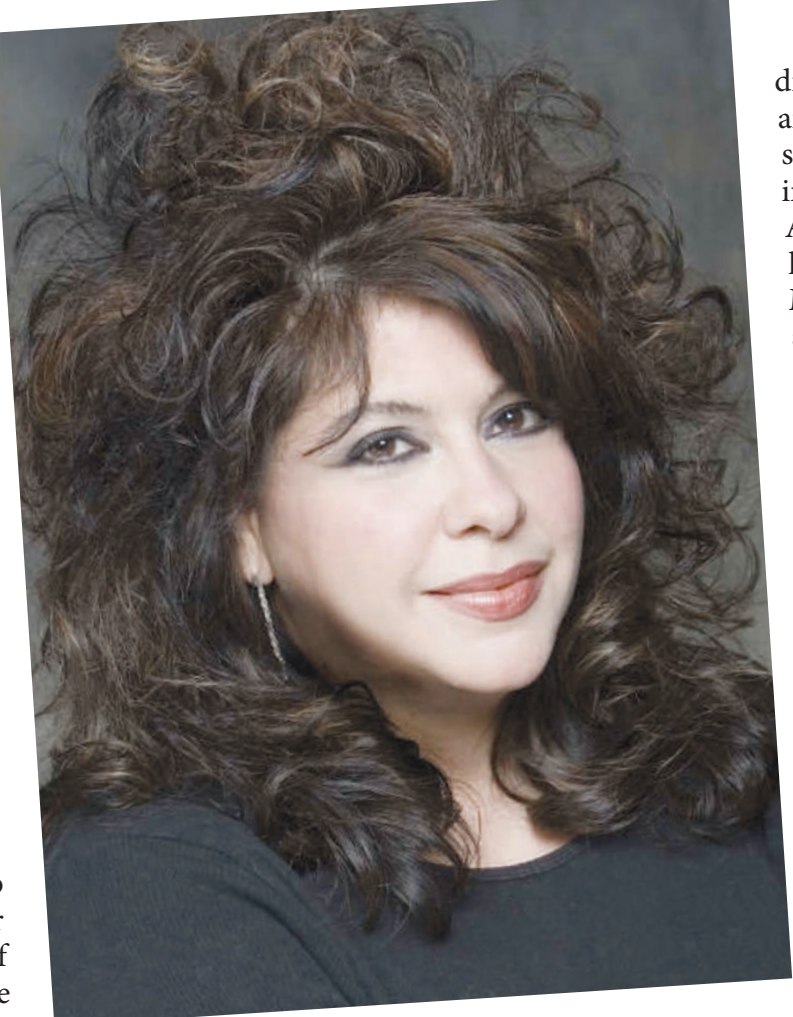

Ectodermal appendages: Angela Christiano leads a research life that is shaped by hair.

got married. But by that time, school had already kindled in her a love for genetics, and she was the first of her family to attend college and earn a PhD, at Rutgers University in New Jersey. She didn't abandon her roots though. Having watched so many hours of beautification, she found herself drawn to dermatology. "It is one of the only areas in medicine where visual things provide clues," she says. "Once I was exposed to a skin disease it was like instant love."

The subject is rarely the focus of such enthusiasm; indeed, dermatology is sometimes given short shrift in medicine. Very few derma-

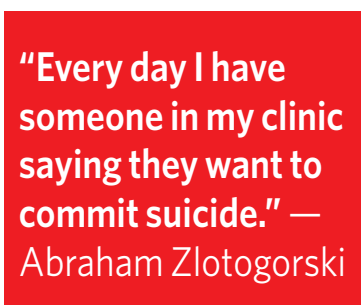
the hall took a closer look and let out "the most blood-curdling scream I've ever heard", Christiano recalls. The spot was the size of an orange. In her new apartment, the blocked shower that she had attributed to bad Manhattan drains turned out to contain a clump of her hair.

Christiano was diagnosed with alopecia areata, a disease in which the immune system attacks hair follicles, causing hair to fall out in patches, or sometimes completely. Because the stem cells in the follicles escape the attack, the hair sometimes grows back, and the condition can come and go throughout life. Christiano had known that tological conditions are life threatening, and a concern with unsightly skin or hair can be dismissed as vanity. As a result, those working in the field take great pains to spell out the hair problems ran in her family: her mother and grandmother both developed female pattern baldness and wore wigs. Now she learned that a distant cousin had a more severe form of 
